\title{
Lope de Vega and the Meanings of Book Ownership ${ }^{1}$ \\ Lope de Vega ante la posesión de libros
}

\author{
Leyla Rouhi \\ Williams College \\ ESTADOS UNIDOS \\ Irouhi@williams.edu \\ [Hipogrifo, (issn: 2328-1308), 4.1, 2016, pp. 255-269] \\ Recibido: 13-08-2015 / Aceptado: 14-09-2015 \\ DOI: http://dx.doi.org/10.13035/H.2016.04.01.17
}

Abstract. Lope de Vega's late poem «Ayer vi la librería» appears at first sight to be a laudatory description of King Felipe IV's personal library. Upon close inspection, and within the broader context of book history in Spain, the poem brings to light a quiet ambivalence about book ownership. This is related at once to Lope's own disappointments with the Monarchy and the contradictory attitudes to the functions of books in Spain in the XVIIth century.

Keywords. Lope de Vega, Books, Tomé de Burguillos, Felipe IV, Ambivalence.

Resumen. El poema de Lope de Vega «Ayer vi la librería» parece a primera vista ser una descripción laudatoria de la biblioteca privada del rey Felipe IV. Un examen minucioso del poema, además del contexto de la historia del libro en España, revelan una ambivalencia latente por parte del poeta en cuanto a la posesión de libros. Se relaciona dicha ambivalencia con el desegaño del poeta respecto a la monarquía tanto como las actitudes contradictorias hacia la función del libro en la España del siglo XVII.

Palabras clave. Lope de Vega, libros, Tomé de Burguillos, Felipe IV, ambivalencia.

Ayer vi la librería,

don Juan, de su Magestad,

con tanta curiosidad

que pintada parecía;

1. I am deeply grateful to Edan Dekel, Simone Pinet, María Judith Feliciano, Julie Cassiday and Silvio Resuli for substantial help with the evolution of this piece. Equal thanks to the Fellows of the Oakley Center at Williams College for their guidance and insights. 


$$
\begin{aligned}
& \text { si entre tanta monarquía } \\
& \text { no puede naturaleza } \\
& \text { extenderse a más riqueza, } \\
& \text { el saber tanto la excede, } \\
& \text { que sólo el ser sabio puede } \\
& \text { añadir a un rey grandeza². }
\end{aligned}
$$

These are the opening lines of a poem by Lope de Vega from his last collection of poetry, Rimas humanas y divinas del licenciado Tomé de Burguillos published in 1634. The poet's visit to King Felipe IV's private library at the Torre Alta del Alcázar de Madrid is described here to a friend named don Juan Infante de Olivares. Today the library no longer exists, but thanks to its meticulous reconstruction in separate studies by Fernando Bouza and Elena Santiago Páez it is known that the King's books were arranged into forty categories and comprised fifteen languages, totaling around 2300 volumes $^{3}$. We have a detailed picture of the books, editions, bindings, shelf organization and furniture of the library, not to mention the network of names and positions of the parties involved in its construction and the gathering of its contents.

Bouza and Santiago Páez each use the poem to ascertain literal facts about the library and the books, noting that the poem has a glorifying and propagandistic mission in the service of the Monarch's image. They observe that the poem evokes the grandeur of this library as opposed to the ostentation seen in other private collections or the majesty of a Vatican or an Escorial. This, then, is primarily a library made for the King's private reading, composed of texts that make him the ideal monarch that he is, and not a place for showiness ${ }^{4}$. The King had been advised to read amply in order to be a better diplomat, Christian, and ruler; the books therefore fulfilled a practical function.

The poem is indeed a useful resource for the reconstruction of the library, but a deeper analysis reveals much more than just a laudatory description of the space and its contents. What emerges is a complex attitude towards book ownership and the meaning of books as material objects. In fact, Lope stages a compelling representation of the ambivalent status of books within the cultural landscape of his time.

The first association in the poem links the library to a painting: «pintada parecía», offering a strong connection to artifice, albeit one to be admired:

$$
\begin{aligned}
& \text { con tanta curiosidad } \\
& \text { que pintada parecía; } \\
& \text { si entre tanta monarquía } \\
& \text { no puede naturaleza } \\
& \text { extenderse a más riqueza, }
\end{aligned}
$$

2. Lope de Vega, Rimas humanas y divinas del licenciado Tomé de Burguillos, vv. 1-10, p. 561.

3. Bouza, 2005; Santiago Páez, 1996, pp. 285-314

4. The relationship between ostentation and books was richly explored in the early modern period. Books were used to showcase status and wealth, especially in ornate private libraries. See Lisa Jardine, 1996. 


\title{
el saber tanto lo excede que sólo el ser sabio puede añadir a un rey grandeza 5 .
}

Lope establishes a network between nature, riches, and wisdom, stating that monarchy's grandeur is so vast that the only thing that could possibly add to it is «el ser sabio». By implication, books have a power to enhance a King's greatness, a notion that the poet substantiates by invoking the sayings of Aristotle. Here he skillfully slips in his own erudition in the service of confirming the King's greatness: that is, he establishes his own authority to understand and direct the purpose of books.

Lope then takes us into the library. He sets up a contrast with the Vatican and the Escorial («El estudio no es igual / al Vaticano de Roma»), emphasizing the private yet accessible nature of the books in the «estudio» of the King ${ }^{6}$. At this point, metaphor takes over and the books come alive:

\author{
Por guarnecerlos sospecho \\ que se transformó en vitela \\ Júpiter, o fue cautela \\ pasar de Europa el estrecho. \\ No hay Cintas, y fue bien hecho: \\ que es en colores distintas \\ sacar naipes por las pintas; \\ ni es gravedad ni es favor \\ hacer regacho un autor \\ con su capotilllo y cintas.
}

Otros, haciéndolos aves, los enjaulan, porque estén seguros, y no hacen bien, habiendo puertas y llaves. El prender autores graves, don Juan, por crueldad tened, que no es hacerles merced ese modo de lisonjas: que no son los libros monjas, que se han de hablar por la red?.

The library is now a stage and the books characters that take on different identities: fighting for the King's attention; transformed by Jupiter in their bindings; contrasted with nuns behind sealed windows and birds in cages as well as with needlessly colorful books that would resemble uniformed pageboys; not «impertinentes libros que espantan las gentes» but «lo selecto sólo» for the King, presented as Apollo ${ }^{8}$. Here, the books become actors under the guidance of the dramatist who 
puts metaphorical masks on the characters, notices their costume and place on the stage, then moves to the next possibility of metaphorical use and misuse for the book ${ }^{9}$. If there is stress on accessibility and simplicity -in contrast to so many libraries where ornamentation and lack of access are distinct features -there is also a hint of humble-bragging. That is, the simple bindings do suggest lack of ostentation, but semi-buried in these references to Jupiter, Europa, and the absence of ornament is the calculated conceit of simplicity. Think of how a tastefully minimalist, understated living room woos us more than an overly furnished and loud one. Thus, even as we watch both good and bad practices in book ownership briefly dramatized before us, there is a suggestion of deliberate design behind the simplicity that betrays a heightened awareness of its impact: «Por guarnecerlos sospecho / que se transformó en vitela / Júpiter, o fue cautela / pasar de Europa el estrecho. / No hay Cintas, y fue bien hecho».

In typical Lopean fashion, the verses change register throughout and now and again even become playful. The elaborate metaphors involving birds, cages, keys, doors, and locks, all praise the King's admirable choice to keep his books on open shelves. But the verses also evoke images that divert from serious monastic learning. They equate imprisoned books with cloistered nuns who speak through grilled windows with the outside world. Here the gaze of the poet is humorously erotic in light of the possible sexual connotations of nuns, confirmed again by the suggestion of lubriciousness in the image of fluttering yet caged birds, anchoring the poem to an earthly setting. The decidedly profane sounds and images of «naipes», «regacho» and «capotillo» spice up the serious library with playful references adding to the cast of colorful characters lurking elsewhere.

If the books are simple in binding, the other objects in the space firmly suggest luxury. Lope turns his gaze to the space that houses the books, seamlessly moving between mimesis and metaphor as he describes two magnificent globes, the study, «dos bufetes», «la escribanía», and the «pomo» that contains «agua de ámbar»". Here he displays his erudition again by linking these to mythology and various sentenciae. His critical explication of the space re-asserts his authority on the uses of objects and spaces related to books. This is confirmed when he speculates even on the objects he cannot fully see:

Dos globos grandes, don Juan,

celeste y terrestre, vi

aunque no los conocí,

cubiertos de tafetán

con justa causa lo están

9. Isabel Torres, 2008, has noted that «there is no doubt that the figure(s) who speak throughout Lope's lyric trajectory (whether wearing pastoral, Moorish, Petrarchan, sacred or parodic masks) are performing subjects», p. 275

10. Lope, Rimas, vv. 930-936. For an insightful study of metaphor and mimesis in Lope's poetics, see Mary Gaylord Randel, 1986. 
que si en el segundo toco,

a imaginar me provoco ${ }^{11}$.

Red fabric covers the writing desk, the globes are draped in taffeta, the glass vase contains essence of amber. Mythology and history command the metaphors in this area: Apollo, Alexander, Parnassus, Aganippe, infuse the physical space with a definitive air of luxury and power that contrasts previous claims about the simplicity of the books. By now the accumulation of classical imagery and sentenciae has, in fact, created the image of a grand project, and the initial statement that this is no Vatican or Escorial has begun to fade.

This clear impression of grandeur prepares the poem for its climax that ends on books as related to Spanish identity. That is, Lope now connects the library specifically to Spain, and highlights the markers that point to the importance of the library for the Spanish ruler. First he names a book in the collection, Francesco Guicciadini's Storia d'Italia, translated into Spanish «que porque bien habló d'España / hizo que hablase Español»12. Guicciadini had been Italy's ambassador to Spain during the reign of Fernando el Católico, and Felipe IV had a special link to the Storia d'Italia: he had ordered its translation, and himself written an Epilogue to it. In this Epilogue Felipe IV outlines his important personal relationship with the Storia and the utility of this translation in his own formation as ruler ${ }^{13}$. The next mention is of Francisco de Rioja who provided the index to the library books and was the King's librarian. Having established the close link of the library to Spanish Kingship and book collecting, Lope concludes:

$$
\begin{aligned}
& \text { Éste es el museo hispano, } \\
& \text { diamante de librerías, } \\
& \text { en quien de dos monarquías } \\
& \text { deje el peso peregrino } \\
& \text { un estudiante divino } \\
& \text { las horas de algunos días }{ }^{14} \text {. }
\end{aligned}
$$

The cast takes its final bow, with the King - «el estudiante divino» - as the main actor, and the memory of the Vatican and the Escorial becomes even more pale set against this new dazzling display, the «diamante de librerías». By the time we reach the «museo hispano» we are in aggrandized territory after ventures into classical myth, the Vatican, and Rome. The poem returns firmly to Spain with its climactic ending, the assertive deictic «Éste» landing unequivocally on Hispanicity. Lope recalls that Spanish nature is bound to the two monarchies, signifying the Divine and the Earthly, emphasizing the religious aspect again with «divino» as the adjective for the student-King, and a pun on «peregrino» which, while here means «unusual» or «extraordinary», also recalls «pilgrim». This is a Spanish museum, intimately linked in its linguistic recreation to local images such as nuns, the poet's friend don Juan

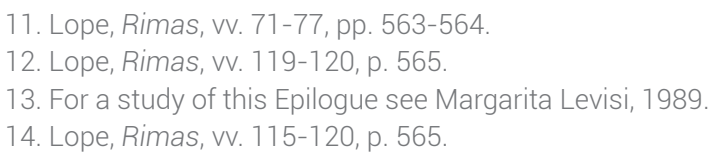


Infante, and the Sevillan man of letters Rioja (who indexed the library). And to one other invisible fact, not mentioned in the poem but apparent once we uncover the context further: Lope's own books in the library.

The list of contents of Felipe IV's library is preserved in a manuscript at the National Library in Madrid, and provides the title and author of each book, with a few explanatory lines on editor and content. From Bouza's careful transcription we know that in the section titled «Poetas españoles» the King's shelves held at least twelve collections of poetry and drama by Lope. The collection from which our poem comes (Rimas humanas y divinas) appears in the King's holdings as well. The poem that praises the library turns out to be one of the many jewels inside the library, with its composer prominently present in the catalogue and now physically present in the library. The connection of the library to its own hispanicity is confirmed once again.

At this point it is useful to pause and consider the broader frame of the poem. The Rimas humanas y divinas del licenciado Tomé de Burguillos, in which this particular staging appears, are known for their parodic and highly cynical tenor. In this collection, which was to be his last, the older Lope dismantles and critiques «fossilized language» and «the pretensions of authoritative discourse» showing deep disillusion for the false erudition and betrayal he sees around him ${ }^{15}$. This disenchantment, expressed mostly through parody, stems in part from Lope's failure to secure the post of «cronista real» which he had repeatedly tried to obtain, being passed over in favor of one José Pellicer de Tovar whom Lope considered a cheap rip-off of Góngora, himself not a favorite of Lope's. Pellicer belonged to a group that one might call literary intelligentsia today, «bien vistos en la Corte, bien relacionados allí, y que gozaban de la Amistad y de la protección del propio rey Felipe IV $\rangle^{16}$. Lope disdained this group, calling them «pájaros nuevos», frustrated by the royal attention to their superficial and false erudition to the extent that «le [hizo a Lope] revolverse contra Palacio, y aún contra el propio Rey Felipe $\mid V{ }^{{ }^{17}}$. This was not the only source of desengaño for our poet; wealth, justice, and noble patronage are also targets in this collection ${ }^{18}$. In addition, the heteronym Tomé de Burguillos, meticulously put together to foreground powerful parodic connotations, suggests a move away from the material world and towards a more ascetic plane along the lines of baroque desengaño ${ }^{19}$. The alter-ego Tomé de Burguillos is «consciously judgmental, often frustrated, and occasionally humorous « acting as a mouthpiece for a Lope who «has already witnessed a fair amount of fighting and alliance-forging in the literary world» ${ }^{20}$.

As it happens, our poem is not in the voice of Tomé de Burguillos as it is clearly recounted by Lope, yet as we have seen an underlying irony is still present in

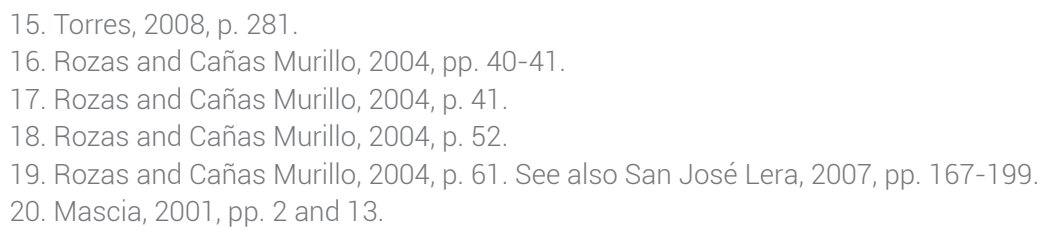


the presence of luxury within a supposedly purely intellectual mission, strengthened by the overarching framework provided by Tomé. Books here are objects to be displayed and performed, carrying hints of showiness and physicality. There is, then, an understated resistance to a stable image of book ownership as a uniformly laudatory fact; and this resistance is best understood in the wider context of book history in Spain.

Information on the book in medieval and early modern Iberia abounds. There is no shortage of data on personal, university, royal, and monastic collections; on bibliophiles, bindings, typesets, commercial networks, colophons, the layout of university and cathedral libraries; trade routes that promoted book buying and selling, to name just some of the many rubrics with which scholars have studied the book. A significant part of this work is quantitative and catalogue-shaped, remarkably useful as data, but minable also for questions of cultural identity ${ }^{21}$. What did books mean to their owners? Is there anything about attitudes to the possession, display, and consumption of books that we can characterize to understand facets of early modern Spanish identity? As with so much else related to early modern Spain, the answer to this depends on region, language, social class, and time period, to name just a few vital parameters. In its quiet ambivalences, Lope's poem turns out to be a productive inroad into a particular characterization of book ownership.

Scholars of the book with little knowledge of Spain have typically neglected the country's early modern book production, largely inspired by the dismissal of the Spanish printing industry in what is considered a seminal study of the book as object. Lucien Febvre and Henri-Jean Martin - whose L'apparition du livre (1958) has guided generations of scholars of the book - offer «a rather bleak and reductionist assessment of the Spanish printing industry in the early Golden Age» ${ }^{22}$. Indeed, in many trans-national studies on medieval and early modern material culture, Spain only receives a few pages or lines, its books often perceived as having «poor material and intellectual quality», reliant on foreign presses for its needs, though some recent studies have begun to correct this image ${ }^{23}$.

Spain did indeed have a thriving print culture, and Spanish printing in the fifteenth, sixteenth and seventeenth centuries was closely interwoven with cultural identity. Unlike Italy, France, and Germany, publishing in Spain, similar to England, was predominantly in the vernacular:

21. «La tendencia reciente de la historiografía a la cuantificación parece distorsionar una realidad social, sólo perceptible de forma cualitativa. La acumulación de datos oculta actividades intelectuales como la lectura, por otra parte difícilmente comprensibles a través de valoraciones cuantitativas. Aún más. Las fuentes tomadas en consideración no presentan una homogeneidad informativa sobre los fenómenos libro, biblioteca y sus respectivas difusiones sociales. Los inventarios post mortem privilegian a unos grupos sociales marginando a otros; ¿es que no leían? ¿por qué no se valoran otras fuentes? ¿Por qué no se define primero el campo de investigación y posteriormente se localizan las fuentes?» (Gimeno Blay and Trencha Odena, 1992, p. 209).

22. Wilkinson, 2012, p. 491

23. Wilkinson, 2012, p. 491. Several recent studies that address material and book culture in Spain are Cruz and Hernández, 2013; De Armas and Barnard, 2013; Gómez Bravo, 2013. 
[There was] a relatively low percentage of books printed in Latin [...] [O]nly about two fifths of all books produced in Spain and Portugal were in Latin. From the very earliest stages, vernacular literature dominated the presses [...] Arguably, it is this low level of scholarly publishing which has shaped the very negative view of the Iberian book world epitomized by Febvre and Martin²4

Another noteworthy fact is that in the fifteenth century, the most important and influential printers in Spain were of foreign, often Northern European, origin, and their impact continued through the second half of the following century ${ }^{25}$. In the early part of the sixteenth century, the famous Complutense Polyglot Bible, a point of pride and joy for Cardinal Francisco de Cisneros and often hailed as one of the markers of the Spanish Empire, «depended largely for its execution on immigrant workers and imported types [i.e typefaces]» 26 . Books came to Iberia largely by import, with the French dominating trade with Spain until the last third of the century when the Dutch took over that role ${ }^{27}$. So from the very start, the Spanish relationship with books was heavily colored by dependence on and interaction with foreigners. Book production was not a purely native craft or business, and required connection to the outside world. After the Council of Trent, this connection to the many immigrants and foreigners involved in book production created tension because these immigrants either had, or were thought to have, Protestant inklings. Clive Griffin's eminently readable Journeymen-Printers, Heresy, and the Inquisition in Sixteenth-Century Spain tells that particular story, and brings home the extent to which people involved in print and the book trade were subject to Inquisitorial harassment ${ }^{28}$. One realizes that the history of the book in Spain -that is, the book as material object, something that is physically made- is as much linked with the Inquisition as the history of ideas and readership. As Griffin shows, Inquisition records help us reconstruct the biographies and perception of the many foreign print-makers who built the Spanish book industry. He paints compelling portraits that reveal a great deal about foreigners' lives in Spain in the sixteenth century. They came to Spain attracted by higher wages and the availability of work (France and Geneva had become increasingly difficult labor markets). They rarely mastered the language, spent all their free time together, and were often regarded with hostility and suspicion because of real or imagined Lutheran tendencies. The attitudes to these foreigners help us understand better a contradiction that is by no means unique to Spain, but takes powerful shape there: books were desired, yet suspected and condemned at the same time.

This contradiction became more extended as Spain played a crucial role in the rise of recreational literature in Europe in the 16th century. While the country im-

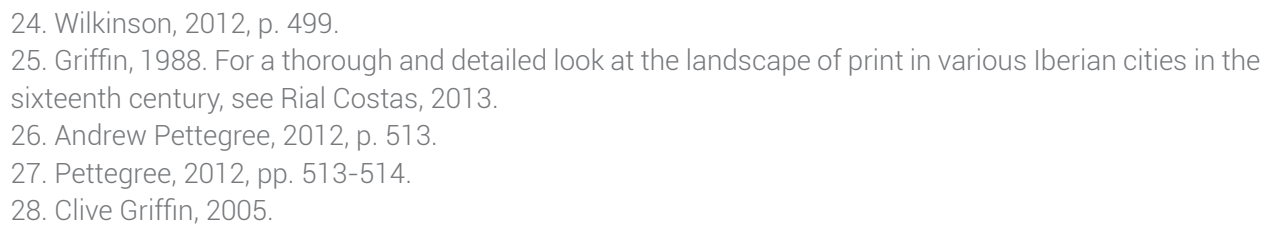


ported classics, Roman and Canon Law, Catholic pastoral theology, the standards by Aristotle and Aquinas, all of which had an audience in Spain, it also

shared generously with the European reading public its own literary traditions. The growth of a new market for recreational literature brought an enormous growth of interest in medieval chivalric romances and related genres, and Spanish was at the heart of this ${ }^{29}$.

Amadís de Gaula, the quintessential romance of chivalry, was by far the most successful in the genre and devoured by readers in French, Dutch, German, Italian, English, and Hebrew. It was published in all formats, «from the luxury illustrated folio [...] to a convenient travellers' sextodecimo» ${ }^{30}$. Writers such as Fernando de Rojas and Diego de San Pedro, who worked in other secular genres, were also wildly popular, but nothing came close to the hunger for Spanish romances of chivalry. The inherent ambivalence that commanded Spain's relationship with books also presided here:

chivalric texts were not uncontroversial. [...] many believed the reading of these texts to be corrupting. The Spanish authorities went so far as to ban Cromberger [a prominent publisher] from including them in consignments of books for the Indies $^{31}$.

In the world of expensive luxury books, the book as object became closely intertwined with the identity of the owner. Elisa Ruiz's fascinating study of queen Isabel I's Books of Hours uncovers the ways in which the queen personalized her «Libros de Horas», for example by using the smaller books as pendants for adornment and protection to carry with her where she went. The book for the wealthy was at once a jewel and a prayer, here showcasing the queen's wealth as well as her staunch catholicism ${ }^{32}$. Princess Margarita de la Cruz, daughter of María of Austria and granddaughter of none other than Charles $V$, surrounded herself with luxury books at the monastery of the Descalzas, forming a deep attachment to some of these as both objects and texts. Upon her death, Felipe IV ordered her saintly biography to be written right away, paying extra attention to the intricate visual and iconographic program of the book's layout, emphasizing once again the connection between physical and textual presence ${ }^{33}$.

Monarchs and noblemen engaged in private library building, and beautiful expensive books in sumptuous private libraries doubled as treasure and text ${ }^{34}$. With the arrival of print, handwritten and dazzlingly illuminated manuscripts began to acquire the status of treasure more visibly. The printed book, often erroneously

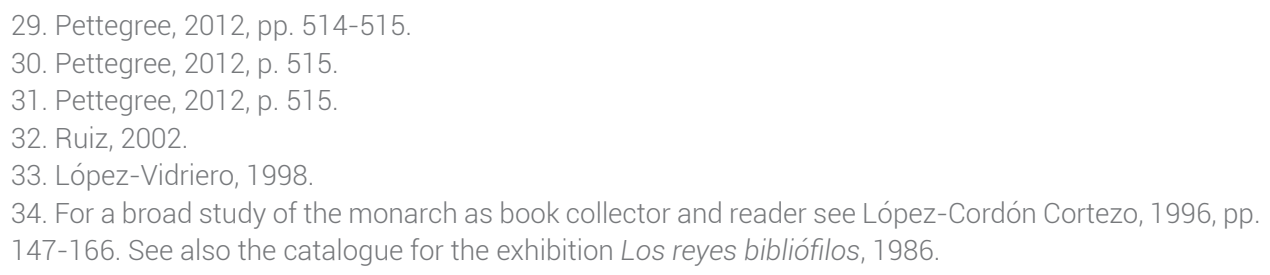


thought of as an equalizing, accessible object, adapted easily to the demands of the wealthy in the shape of special editions, adorning many a high-ranking official's library with ornate and one-of-a-kind samples ${ }^{35}$. Books also became screens for the projection of family issues, as seen in wills and testaments. The humanist Gonzalo García de Santa María (1447-1521) described his library in his will and gave detailed instructions on who in the family may or may not have access to the books after his death. In this will, books become a powerful screen for familial conflict and disappointment, as well as anxieties over ownership. Above all, they come across as the strongest markers of a man's identity and life achievements: "Y no se maraville alguno que tanta diligencia pongo en mis libros, porque segun mi afección, mas valen que todo el resto de mi mueble» ${ }^{36}$.

With Felipe II the relationship between power and the book became more complicated and intense. Nowhere is this more apparent than the Library of the Escorial, a conscious project of Spanish identity-building to construct both a monument and a collection that would equal the Vatican. A serious Counter-Reformation and expansionist drive went into the building of the library and the accumulation of books. The impressive collection was founded on Felipe II's personal holdings as well as active acquisition within Spain and from European countries and the Ottoman Empire. Throughout Spain holdings of sumptuous private libraries found their way into the Escorial after the death of the owners ${ }^{37}$. Felipe II foregrounded the use of books for their luxurious physical presence a much as for their content in many areas related to his image. As Lisa Jardine explains, the King commissioned the Antwerp printer Christophe Plantin to print the official tribute to Philip's father with a full state subsidy; a magnificent and sumptuous volume giving the «Account of the Funeral Ceremonies of Charles $V_{{ }^{\prime}}{ }^{38}$. It is useful to note how Plantin came to obtain this commission: by singing Felipe II's «virtues and talents» in an unsolicited small volume of verse that he boldly sent to the King,

printed in an elegant italic typeface, with several ornamental initial letters. The eight pages of text were bound in an elaborate morocco-leather binding, the centerpiece of whose intricate tooled front cover was an oval panel with Philip's title incised upon it ${ }^{39}$.

The object did its job: it effectively seduced the King to employ Plantin and to make the Dutchman responsible for many ever-important official publications. The power of the luxury book could hardly be over-stated in this case ${ }^{40}$. But in all of these projects, the quintessential fact of a fundamental ambivalence about the very object being produced remained present.

35. See in particular Revenga and López-Vidriero, 1985; Sánchez Mariana, 1993.

36. Quoted in Pedraza García, 2008, p. 346.

37. The bibliography on the Escorial library is vast. For a good start see El libro antiguo español III (1996).

38. Jardine, 1996 , p. 220.

39. Jardine, 1996, p. 219.

40. Philip II's textual and visual propaganda machine is studied in detail by Fernando Bouza, 1998. 
The ambivalence came from the belief that books were at once useful and dangerous. This is of course not a new idea. As long as repositories of information have existed, some have considered them useful and others have worried about the harm they can do. In the case of Counter-Reformation Spain though, even a project such as the building of the Escorial rested upon hiding, editing, and correcting books alongside their display. The paranoia surrounding Protestant material was so intense that no act of book-acquisition or edition came without a simultaneous accusation against books, and often the same person fulfilled both functions. From Felipe II to men of books such as Cardinal Sirleto, Benito Arias Montano, or Juan Bautista Cardona, all fulfilled at once the mission of propagators of books as well as its censors ${ }^{41}$. In the production of the book as physical object, especially with liturgical material mandated by the Council of Trent, Felipe II was every bit the micro-manager: the King oversaw and gave advice on Plantin's publications, errata, typesets, illustrations, and even projections on what kinds of layouts might sell better ${ }^{42}$. The King solidified his authority by interfering directly with his subjects' reading habits and determining even the physical attributes of devotional books.

Furthermore, not everyone considered the collection and ownership of expensive books a good thing. If we pause for a minute here on the topic of luxury, it is important to note that by the 18th century, the pros and cons of luxury had become a serious topic of debate in Europe. In France, Rousseau lamented the evils and wickedness brought about by luxury while Jean-François Melon, once secretary to John Law and author of Essai politique sur le commerce adamantly rejected the idea that luxury promoted immorality ${ }^{43}$. The underlying conflict stemmed from the assertion that clearly, owning fine objects made people happy, but that this happiness centered on a selfish desire to accumulate objects at the expense of moral virtue:

with the gradual emergence of a commercial society, the individual pursuit of happiness, rather than the pursuit of virtue (and, even less, the attainment of personal salvation) came increasingly to denote the summum bonum of human existence $^{44}$.

This debate emerged in Spain as well, with examples of a staunch condemnation of luxury in letters and essays as seen for example in the the 1789 Efectos perniciosos del lujo: Las cartas de D. Manuel Romero del Alamo al Memorial literario de Madrid. In the realm of books and well before the eighteenth century, the idea of reading as dangerous and immoral was of course no news: reading, especially for women (and for men called don Quijote) had long been identified as in dire need of regulation by many theologians and moralists. As for the physical book, the ostentation and vanity connected with collecting did not go unnoticed either. National and private collections grew, but false erudition and shelves of expensive

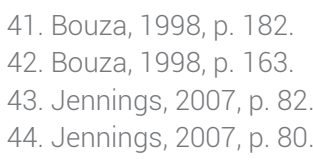


unread books were condemned by moralists and authors; Lope himself offered a critique of the vanity of printing and books in a lively exchange between Barrildo and Leonelo early in Act II of Fuenteovejuna, and the famous Prologue of Don Quijote I is, among other things, a scathing satire on authors who show off their superficial knowledge. Likewise, the frequent praise for letters and learning -laudes litterarum - was countered by parodies of the book and the library. There were misgivings about the very nature of learning, considered vain, as portrayed in many emblems and paintings ${ }^{45}$. All this ambivalence -the paranoid vigilance about imports for fear of heretical materials, the concern about reading and luxury, yet at the same time a desire to make books and to collect and read them- only aggravated the constant push-and-pull movement that governed the attitudes towards book production and consumption in Spain.

We can now appreciate the intricate play of registers and metaphor in Lope's poem more fully. The constant shifts between mimesis and metaphor, the references to the divine and the profane, the lively glimpses of the everyday that interrupt the grand notions, all embody the multi-faceted debate about books as objects in his time even though the poem purports to be in complete praise of the library, with Lope's physical presence in it as a celebration of his achievements.

As mentioned earlier, Lope did not hide his disdain for the choice of Pellicer and the circle of men whom he considered false and vain intellects, nor was his disappointment at the Monarch a secret. Even Lope's books on the shelves of Felipe IV's library, then, do not tell a completely happy story, especially if we turn a few pages within the Rimas and look at a later sonnet in the collection:

«Discúlpase el poeta del estilo humilde»:

Sacras luzes del cielo, yo he cantado en otra lira lo que avéis oído; saltó la prima y el bordón lo ha sido al nuevo estilo, si le avéis culpado.

De mí mismo se burla mi cuidado, viéndome a tal estado reduzido; pero, pues no me avéis favorecido, ¿por qué disculpo lo que avéis causado?

Entre tantos estudios os admire, y entre tantas lisonjas de señores, que de necessidad tal vez suspire;

mas tengo un bien en tantos disfavores, que no es possible que la embidia mire: dos libros, tres pinturas, quatro flores ${ }^{46}$.

45. Fernando de la Flor, 1999.

46. Lope, Rimas, p. 425. Juan Manuel Rozas studies this poem in http://www.cervantesvirtual.com/ obra-visor/sacras-luzes-del-cielo-el-soneto-161-de-burguillos-un-epifonema-de-sus-rimas-humanas-y-divinas-y-de-la-obra-potica-de-lope-0/html/ffa3f66e-82b1-11df-acc7-002185ce6064_2.html. In a lengthier essay (Rozas, 2002), the scholar traces Lope's disenchantment in detail. 
In a study of the sonnet, Juan Manuel Rozas points out that as humble as the posture may be here, there is «protesta social por los tiempos que no están para hablar de veras y sí para parodiar el mundo, literaria, social o institucionalmente» ${ }^{47}$. Here is a man who has worked all his life to uphold the system, and is now left unrewarded by the same system. In this poem his bitterness is remedied by a simple life governed by the intellect because, as the poem suggests, Lope believes he is a very good poet and a first-rate intellect. Now that high-ranking gentlemen and, by implication, the monarch himself, have disappointed him, all he needs are «dos libros, tres pinturas, quatro flores». An image of authentic simplicity that stands in contrast to the complicated simplicity of the King's library. This sonnet quietly challenges the glories and the constructed simplicity celebrated at the Torre, picking up on that hint of parody we heard there first, now more loudly manifested as true discontent in the tiny library of the poet that brings him peace.

We have here a display of two facets of Spanish identity intertwined with books: the monarch sits atop his many books in calculated lack of ostentation with an admirable spatial design that inspires awe. The Baroque poet dutifully sees all that and describes it in true conceptista style. But in his description, he encodes enough shifts to alert the reader to the cracks within the system.

Both poems challenge any binary of being pro or against books. That binary stands on a contradiction, apparent in the paranoia that surrounds book production and ownership: on the one hand, the hysterical Inquisition, the zealous moralist tracts, censorship, frantic micro-management. On the other hand, grandiose projects of commissioning and collecting precious books, building sumptuous rooms for them, and showing them off. As though in defiance of all this, at the entrance of Lope's house in Madrid is the inscription: «Parva propia magna, magna aliena parva», which can be translated into: «What little I have is a great deal, the great deal that others have is little». Here, as with the two poems, mere contradiction is transcended and turned instead into description layered with nuance. In spite of the oppressive apparatus that governed speech and writing, and of which he had been a part at a time, Lope leaves us one of the most suggestive descriptions of book ownership in his era.

BIBLIOGRAPHY

Bouza, Fernando, Imagen y propaganda: capítulos de historia cultural del reinado de Felipe II, Madrid, Akal, 1998.

Bouza, Fernando, El libro y el cetro: la biblioteca de Felipe IV et la Torre Alta del Alcázar de Madrid, Salamanca, Instituto de la Historia del Libro y de la Lectura, 2005.

47. Rozas, http://www.cervantesvirtual.com/obra-visor/sacras-luzes-del-cielo-el-soneto-161-deburguillos-un-epifonema-de-sus-rimas-humanas-y-divinas-y-de-la-obra-potica-de-lope-0/html/ ffa3f66e-82b1-11df-acc7-002185ce6064_2.html. 
Cruz, Anne J. and Rosilie Hernández, Women's Literacy in Early Modern Spain and the New World, Burlington, Ashgate Publishing, 2013.

De Armas, Frederick A. and Mary E. Barnard, Objects of Culture in the Literature of Spain, Toronto, University of Toronto Press, 2013.

Flor, Fernando de la, «"Vanitas:" representaciones figurativas del libro como jeroglífico de un saber contingente», en El libro antiguo español V: el escrito en el Siglo de Oro. Prácticas y representaciones, ed. Pedro M. Cátedra, María Luisa López-Vidriero y Augustin Redondo, Salamanca, Universidad de Salamanca, 1999, pp. 217-240.

Gaylord Randel, Mary, «Proper Language and Language as Property: The Personal Poetics of Lope's Rimas», Modern Language Notes, 101, 2, Hispanic Issue, 1986, pp. 220-246.

Gómez Bravo, Ana, Textual Agency: Writing Culture and Social Networks in Fifteenth-Century Spain, Toronto, University of Toronto Press, 2013.

Gimeno Blay, Francisco M. y José Trenchs Odena, «Libro y bibliotecas en la Corona de Aragón, (siglo XVI)», en El libro antiguo español, II, ed. María Luisa López Vidriero and Pedro Cátedra, Salamanca y Madrid, Sociedad Española de Historia del Libro, 1992, pp. 207-229.

Griffin, Clive, The Crombergers of Seville: The History of a Printing and Merchant Dynasty, Oxford, Oxford University Press, 1988.

Griffin, Clive, Journeymen-Printers, Heresy, and the Inquisition in Sixteenth-Century Spain, Oxford, Oxford University Press, 2005.

Jardine, Lisa, Worldly Goods: A New History of the Renaissance, New York, Doubleday, 1996.

Jennings, Jeremy, «The Debate about Luxury in Eighteenth and Nineteenth-century French Political Thought», Journal of the History of Ideas 63, 1, 2007, pp. 79105

Levisi, Margarita, «Hacia una historia de la autobiografía española: un texto de Felipe IV», Bulletin of Hispanic Studies, LXVI, 1989, pp. 119-128.

López-Cordón Cortezo, María Victoria, «Libros y pedagogía», en El Libro Antiguo Español III, El libro en Palacio y otros estudios bibliográficos, ed. María Luisa López Vidriero y Pedro M. Cátedra, Salamanca y Madrid, Sociedad Española de Historia del Libro, 1996, pp. 147-166.

López-Vidriero, María Luisa, «Por la imprenta hacia Dios», en El libro antiguo español VI: de libros, librerías, imprentas, lectores, ed. Pablo Andrés Escapa, Salamanca, Universidad de Salamanca, 2002, pp. 193-218.

Mascia, Mark, «To Live Vicariously Through Literature: Lope de Vega and his Alter Ego in the Sonnets of Rimas humanas y divinas del licenciado Tomé de Burguillos», Romance Studies, 19, 1, 2001, pp. 1-16. 
Pedraza García, Manuel José, El libro español del Renacimiento, Madrid, Arco Libros, 2008.

Pettegree, Andrew, «North and South: Cultural Transmission in the Sixteenth-Century European Book World», Bulletin of Spanish Studies, LXXXIX, 2012, pp. 507-520.

Revenga, Luis and María Luisa López-Vidriero (ed.), Tesoros de España: Ten Centuries of Spanish Books, New York, New York Public Library, 1985.

Revenga, Luis, Los reyes bibliófilos, Madrid, Biblioteca Nacional, 1986.

Rial Costas, Benito, Print Culture and Peripheries in Early Modern Europe: A Contribution to the History of Printing and the Book Trade in Small European and Spanish Cities, Leiden, Brill, 2013.

Rozas, Juan Manuel, <http://www.cervantesvirtual.com/obra-visor/sacras-luzesdel-cielo-el-soneto-161-de-burguillos-un-epifonema-de-sus-rimas-humanas-y-divinas-y-de-la-obra-potica-de-lope-0/html/ffa3f66e-82b1-11 dfacc7-002185ce6064_2.html> ]13/08/2015].

Rozas, Juan Manuel, <http://www.cervantesvirtual.com/obra/lope-de-vega-y-felipe-iv-en-el-ciclo-de-senectute-0/> [13/08/2015].

Ruiz, Elisa, «Los Libros de Horas en los inventarios de Isabel la Católica», en El libro antiguo español VI: de libros, librerías, imprentas, lectores, ed. Pablo Andrés Escapa, Salamanca, Universidad de Salamanca, 2002, pp. 389-419.

San José Lera, Javier, «Tomé de Burguillos y el triunfo del Quijote: una lectura de las Rimas humanas y divinas del licenciado Tomé de Burguillos de Lope de Vega», Criticón, 100, 2007, pp. 167-199.

Sánchez Mariana, Manuel, Bibliófilos españoles desde sus orígenes hasta los albores del siglo XX, Madrid, Ollero y Ramos, 1993.

Santiago Páez, Elena, «"Animi medicamentum": la biblioteca de Felipe IV de la Torre Alta del Alcázar'», en El Libro Antiguo Español III, El libro en Palacio y otros estudios bibliográficos, ed. María Luisa López Vidriero and Pedro M. Cátedra, Salamanca y Madrid, Sociedad Española de Historia del Libro, 1996, pp. 285314.

Torres, Isabel, «Interloping Lope: Transformations and Tomé de Burguillos», Bulletin of Spanish Studies, LXXXV, 3, 2008, pp. 273-288.

Vega, Lope de, Rimas humanas y divinas del licenciado Tomé de Burguillos, ed. Juan Manuel Rozas and Jesús Cañas Murillo, Madrid, Clásicos Castalia, 2004.

Vega, Lope de, Rimas humanas y divinas del licenciado Tomé de Burguillos, ed. Macarena Guiñas Gómez, Madrid. Cátedra, 2008.

Wilkinson, Alexander S., «Exploring the Print World of Early Modern Iberia», Bulletin of Hispanic Studies, LXXXIX, 4, 2012, pp. 491-506. 
